\title{
A New Configuration of Vertically Connecting Solar Cells: Solar Tree
}

\author{
Anouar Bella Baci, ${ }^{1,2}$ Mohamed Salmi, ${ }^{1,2}$ Younes Menni, ${ }^{3}$ Samira Ghafourian, \\ Milad Sadeghzadeh $\left(\mathbb{D},{ }^{5}\right.$ and Mohammad Ghalandari ${ }^{6}{ }^{6}$ \\ ${ }^{1}$ Department of Physics, University of M'sila, M'Sila 28000, Algeria \\ ${ }^{2}$ Laboratory of Physics and Chemistry of Materials (LPCM), University of M'sila, Algeria \\ ${ }^{3}$ Unit of Research on Materials and Renewable Energies, Department of Physics, Faculty of Sciences, Abou Bekr Belkaid University, \\ BP, 119-13000 Tlemcen, Algeria \\ ${ }^{4}$ Faculty of Architecture and Urban Planning, Shahid Beheshti University, Tehran, Iran \\ ${ }^{5}$ Department of Renewable Energy and Environmental Engineering, University of Tehran, Tehran, Iran \\ ${ }^{6}$ Institute of Research and Development, Duy Tan University, Da Nang 550000, Vietnam
}

Correspondence should be addressed to Milad Sadeghzadeh; milad.sadeghzadeh@gmail.com and Mohammad Ghalandari; mohammadghalandari@duytan.edu.vn

Received 19 April 2020; Accepted 8 September 2020; Published 23 September 2020

Academic Editor: Dhruba B. Khadka

Copyright (C) 2020 Anouar Bella Baci et al. This is an open access article distributed under the Creative Commons Attribution License, which permits unrestricted use, distribution, and reproduction in any medium, provided the original work is properly cited.

\begin{abstract}
Solar energy is a renewable type, clean, and inexhaustible which is sufficiently available on the Algerian territory. The energy received daily on a horizontal surface of $1 \mathrm{~m}^{2}$ is in the order of $5 \mathrm{kWh}$ over almost the whole Algerian territory; the duration of sunshine surpasses 2000 hours annually and can reach 3900 hours on the highlands and the Sahara. The importance of this work is based on exploiting solar energy to produce electricity. This study is based on the experimental exploitation of solar energy using solar tree's prototype suggestion. This new model is focused to replace the leaf of a tree by the solar cell, starting by examining the solar field and physical phenomenon related with it; the description of cell photovoltaic comes after; and finally, the dimension of the solar system and the experimental studies are virtually released in the University of M'sila. In this work, a prototype of new artificial solar tree is proposed experimentally by using material available in the local market: 25 solar panels, metal support, electrical queues, regulator, and battery. The results highlight a power improvement in the case of the proposed new model (solar tree) compared to the traditional one provided (solar panel), for the specified time range between 8 am and 2:30 pm. On the other hand, the traditional model values improve if the time dimension is extended from 2:30 pm to 6:00 pm. This is due to the temperature of the region and the presence of interstellar spaces between the cells of the solar tree.
\end{abstract}

\section{Introduction}

In a world that tends towards the exploitation of renewable energy resources, while thinking practically and gradually of the exhaustion of fossil fuels, Algeria is highly called to be up to date because of its natural potential in this field [1-5]. Renewable energy is known for its advantages such as cleanliness and low cost of exploitation for a lifetime of 25 years of electricity production [6,7]. In addition, it helps to avoid greenhouse gases and pollution, and the big advantage is that it is inexhaustible $[8,9]$. In this renewable energy, solar energy represents a huge potential that can be exploited through different technologies [10-13]. Photovoltaic energy $(\mathrm{PV})$ is one of the examples. Due to the global availability of solar energy $[14,15]$, photovoltaics are an interesting solution for electricity generation $[16,17]$.

Several recent studies were conducted to obtain the best conditions for successful PV systems. Katayama et al. [18] gave details on different kinds of degradation and failure in PV cells including potential-induced degradation (PID) and interconnect ribbon, as well as mechanical stress. Hernández-Callejoet et al. [19] discussed in their review the 
hybrid systems and the power quality. Gruber et al. [20] explored the effect of unorganized charge-extraction/transport layers on the measurements of solar cell photocurrent. Antonacci and Scognamiglio [21] were interested in the realization of smart biosensors and the development of hybrid nanostructures composed of photosynthetic elements and nanomaterials. Jeong et al. [22] combined perovskite PV cells and a few-nanometer thin $\mathrm{MoTe}_{2}$ field-effect transistor (FET) for the development of a self-power circuit. By mathematical modeling and simulation, Lakeh et al. [23] studied the effect of some parameters, including the load resistance of TEG, cold side temperature, and other parameters on the efficiency of an integrated thermoelectric-PV cell. For the hydrogen production, Shaygan et al. [24] analyzed the characteristics of a hybrid system. Other studies can be found in the referenced works (Malathy and Ramaprabha [25], Wu et al. [26], Araki and Yamaguchi [27], Wang et al. [28], Merten et al. [29], Kazem and Khatib [30], Ikegami et al. [31], Jha and Triar [32], Quaschning and Hanitsch [33], Xie et al. [34], El Iysaouy et al. [35], Echendu et al. [36], Bouraiou et al. [37], Ciulla et al. [38], Huang et al. [39], Abdul Kadir et al. [40], Chaaban et al. [41], and Ali et al. [42]) for various photovoltaic cell structures and different studied governing parameters.

In Algeria, the equivalent of 300 billion Tep per year in solar energy is received in terms of sunshine; the energy received daily on a horizontal surface in $1 \mathrm{~m}^{2}$ is of the order of $5 \mathrm{kWh}$ on almost the entire Algerian territory. The duration of sunshine exceeds 2000 hours each year and can go up to 3900 hours in the highlands and the Sahara, which is a high average compared to other countries around the world [1]. Solar energy in Algeria has great importance [43-46], but its productivity depends on the area covered by solar panels, so our research problem is how to achieve high efficiency in a very limited space? The proposed solution to this problem is the use of solar or photovoltaic tree. In this work, a small artificial solar tree, which will imitate the appearance of a tree whose leaves are replaced by photovoltaic cells, is presented and the output generated electricity is measured and analyzed.

The present research work is based on the experimentation of solar energy using solar tree's prototype suggestion. This current PV type is focused to replace the leaf of a tree by the solar cell, starting by examining the solar field and physical phenomenon related with it, the description of cell photovoltaic comes after and finally, the dimension of the solar system and the experimental studies are virtually released in the University of M'sila.

\section{Governing Data}

2.1. Constitutions of the PV System. In this section, the different elements that make up the PV installation system are presented. There are 4 main elements constituting a photovoltaic generator system: the PV panel, the battery (storage), the voltage regulator, and the converter (inverter), which are shown in Figure 1, i.e., a solar system with energy storage.

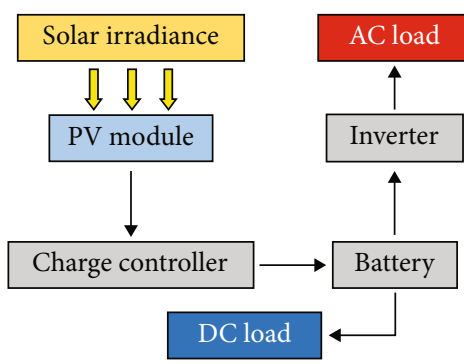

FIGURE 1: Solar system with energy storage.

2.2. Region of M'sila. M'sila, in its current boundaries, occupies a privileged position in the central part of northern Algeria as a whole; it is part of the Central Highland region and covers an area of $18,175 \mathrm{~km}^{2}$.

Its geographical position makes its main vocation remain agropastoralism tributary of an unfortunately low and irregular rainfall not exceeding $250 \mathrm{~mm}$ per year. It is limited to the following:

(i) In the North East: the wilayas of Bordj Bou-Arreridj and Setif

(ii) North West: the wilayas of Medea and Bouira

(iii) In the East: the wilaya of Batna

(iv) To the West: the wilaya of Djelfa

(v) South East: the wilaya of Biskra

Its geographical coordinates are as follows:

(i) Altitude: $477 \mathrm{~m}$

(ii) Latitude: $35^{\circ} 7$ North

(iii) Longitude: $4^{\circ} 54194$ East

2.3. Climate of M'sila. The climate of the region is continentally submitted in part to Saharan influences. Summer is dry and very hot, while the winter is very cold. In terms of rainfall, the most watered zone is located in the north; it receives more than $480 \mathrm{~mm}$ per year; for the rest of the territory, the driest area is located in the extreme south of the Wilaya and receives less than $200 \mathrm{~mm} /$ year. The annual average rainfall of the wilaya in 2010 was $153 \mathrm{~mm}$ per year. The average monthly temperatures of a year were $20^{\circ} \mathrm{C}$, where $32^{\circ} \mathrm{C}$ was recorded in the warmest month (August) and $11^{\circ} \mathrm{C}$ in the coldest month (January). The min and max temperatures recorded were $-0.2^{\circ} \mathrm{C}$ in January and $45.7^{\circ} \mathrm{C}$ in July.

\section{Experimental Study}

3.1. PV Field Orientation. In Algeria and more generally in the entire northern hemisphere, the selected orientation of the PV field towards the south 0 (full south) must be similar to what is represented in Figure 2. 


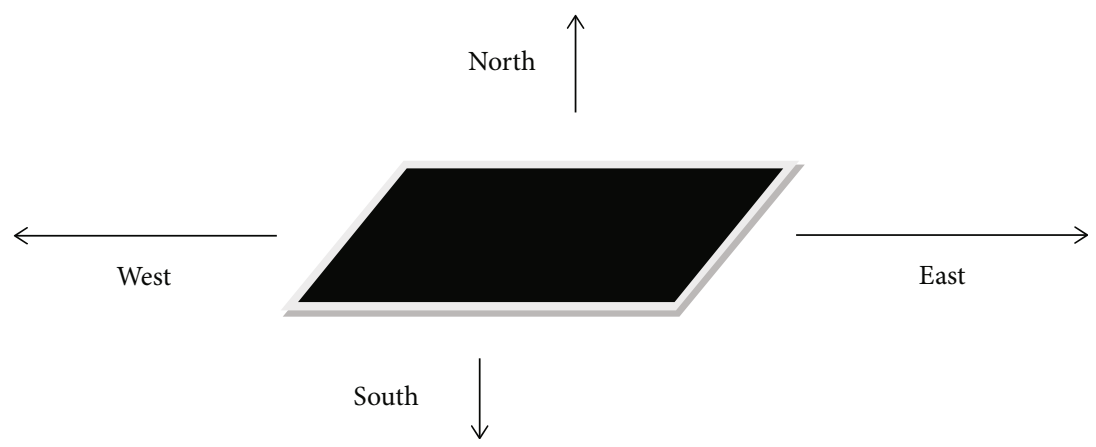

Figure 2: PV field orientation.

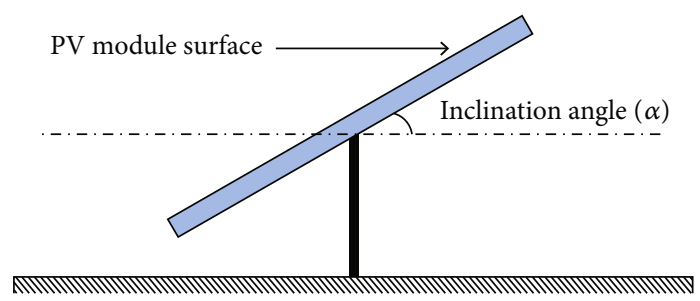

Figure 3: Angle of inclination of photovoltaic modules.

3.2. Inclination Angle. The angle of inclination corresponds to the angle formed by the plane of the solar module relative to the horizontal (see Figure 3).

3.3. Determination of the Solar Field. The solar radiation of the place can be chosen by the following:

(i) Real data measured by metrological stations

(ii) Calculations using by a mathematical model

(iii) Data provided by NASA, PVGIS, and Meteonorm

The average monthly irradiation of " $\mathrm{M}$ 'sila" commune is given by the PVGIS (Photovoltaic GISement). The map of the region of M'sila [47] is shown in Figure 4, and the solar radiation values are mentioned in Table 1 .

The following results were obtained:

(i) The optimum angle of inclination is $35^{\circ} \mathrm{deg}$.

(ii) Annual irradiation lost due to shade

(iii) $H_{\text {opt }}$ : plan irradiation with optimal inclination (Wh/m $/ \mathrm{m}^{2} /$ day)

(iv) $L_{\text {opt }}$ : optimal inclination (deg.)

\section{Realization of Solar Tree}

The proposed solar tree is designed by using the following components.

4.1. Photovoltaic Panel. For the solar tree design [48-50], 25 solar panels (Figure 5) are needed that are characterized by

(i) $P_{\max }=3.0 \mathrm{~W}$ (ii) $V_{\mathrm{oc}}=7.2 \mathrm{~V}$

(iii) $I_{\mathrm{sc}}=0.56 \mathrm{~A}$

(iv) $V_{\mathrm{mp}}=6 \mathrm{~V}$

$I_{\mathrm{mp}}=5 \mathrm{~A}$, and the maximum system voltage is $1000 \mathrm{~V}$.

4.2. Iron Bars. Seven iron bars are required to fix the solar panels where the supports of the leaves are symmetrical and the dimensions are as follows:

(i) Two branches with $1.10 \mathrm{~m}$

(ii) Two branches with $0.9 \mathrm{~m}$

(iii) Three branches with $0.8 \mathrm{~m}$, and the distance with the branches is $0.6 \mathrm{~m}$

4.3. Panel Connection. In this step, the solar cells are fixed on the support taking into account the optimal orientation while avoiding the shadow [51, 52] (see Figure 6).

4.4. Electrical Wiring. $30 \mathrm{~m}$ of electrical wires is provided to connect to the photovoltaic cell $(15 \mathrm{~m}$ by $15 \mathrm{~m}$ red and black color).

4.4.1. Regulator. To calculate the power of solar panels, a regulator with the features is used (Figure 7):

(i) The voltage: $U=12 \mathrm{~V}-24 \mathrm{~V}$

(ii) The current: $I=30 \mathrm{~A}$

4.4.2. Battery. A battery is used to store the load to provide power to electrical equipment; the battery that adapts the energy need is Gel Battery (12 V-150 Ah) (Figure 8).

\section{Results and Discussion}

5.1. Inclination. From our experiments, it was found that the electrical intensity provided by the cells varies in function of the cell inclination, which is maximal when the panel is perpendicular to the light rays. So, it is necessary to monitor the inclination of the sun's rays in relation to the Earth to better orient the panels of our tree.

The experimental study of the designed tree unfolded in the period from May to June by measurements of intensity and tension. So, it is looked for obtaining the 


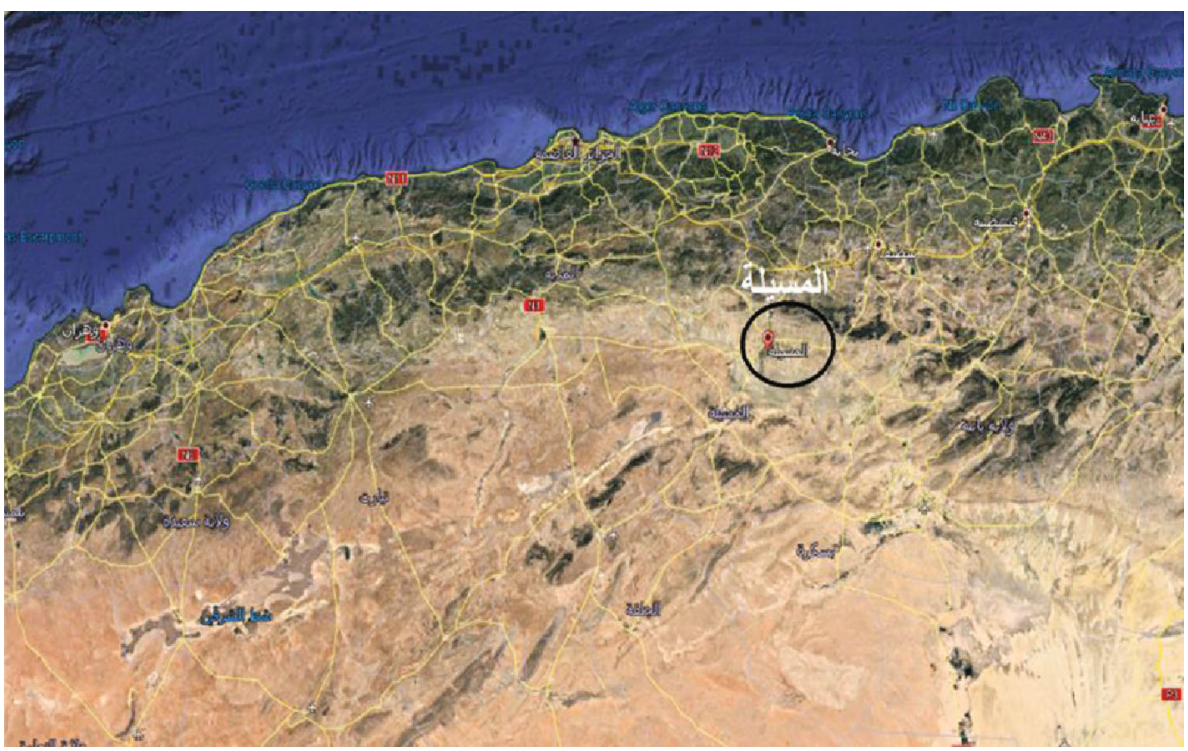

Figure 4: Map of the region of "M'sila."

TABle 1: Monthly average of irradiation in M'sila.

\begin{tabular}{lcc}
\hline Month & $\begin{array}{c}\text { Irradiation with optimal } \\
\text { inclination }\left(H_{\text {opt }}\right)\end{array}$ & $\begin{array}{c}\text { Optimal inclination } \\
\left(L_{\text {opt }}\right)\end{array}$ \\
\hline January & 4790 & $61^{\circ}$ \\
February & 5440 & $53^{\circ}$ \\
March & 6510 & $39^{\circ}$ \\
April & 6590 & $25^{\circ}$ \\
May & 6780 & $11^{\circ}$ \\
June & 7040 & $3^{\circ}$ \\
July & 7250 & $6^{\circ}$ \\
August & 7250 & $18^{\circ}$ \\
September & 6400 & $34^{\circ}$ \\
October & 6100 & $48^{\circ}$ \\
November & 5010 & $58^{\circ}$ \\
December & 4430 & $63^{\circ}$ \\
Year & 6140 & $35^{\circ}$ \\
\hline
\end{tabular}

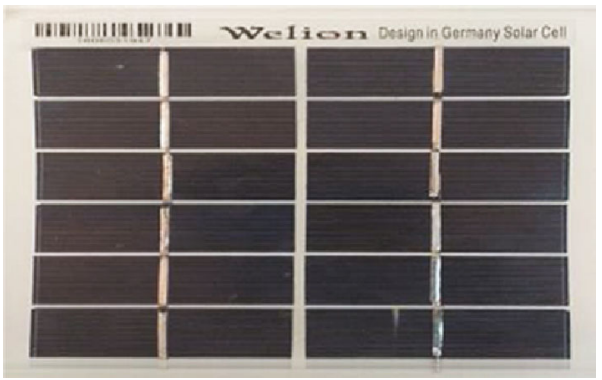

FIGURe 5: Photovoltaic panel.

best inclination with a panel connected to an ammeter. The results of this step are shown in Table 2. So, the solar tree panels are fixed at $33^{\circ}$.
5.2. Connection of Photovoltaic Panels. From our experiments, it was found that the electrical intensity provided by the cells varied by the inclination of the cells (Table 2). This is maximum when the cell is perpendicular to the light rays. We therefore had to look for the inclination of the sun's rays in relation to the Earth in order to best orient the cells of our tree.

The experimental study of our tree takes place in the month period of May and June by measurements of intensity and voltage (Table 3 ). So we fixed the solar tree panels at $35^{\circ}$. The dimension that showed the best connection configuration is three photovoltaic cells in series and fourteen cell branches in parallel.

5.3. Electric Power. To compare the electric power supplied by our tree, a fixed panel inclined at $35^{\circ}$ was built (Figure 9) with the same number of cells and the same electrical connection as our tree. The electrical power was measured at different times of a typical sunny day (Monday, June 18). The fixed panel was oriented south-north while the front face of the tree was south.

Figure 10 shows the variation of the current $(I)$ as a function of voltage $(V)$ for the fixed panels and the solar shaft, respectively. The predicted results of the $I-V$ characteristic are approximately similar to the theoretical results, where the maximum of the measurement error is about $0.18 \%$. As expected, the current changes with the change in the tension. There is an inverse proportionality between the values of $I$ and $V$; whereas $V$ increases, the $I$ intensity decreases, in both cases studied. The comparison of the two models proves that in the case of using the solar panel, it gives high values in terms of $I$ at $V$ less than 20.5 volts. $3.00 \mathrm{~A}$ is reported in the case of the PV first model, i.e., solar panel, at the minimum tension value $(19.5 \mathrm{~V})$, while $3.75 \mathrm{~A}$ is highlighted in the case of the PV second model, i.e., solar tree, at the same $I$ minimum, whereas the two models present the same current strength at 20.5 volts of tension, while there is a difference 

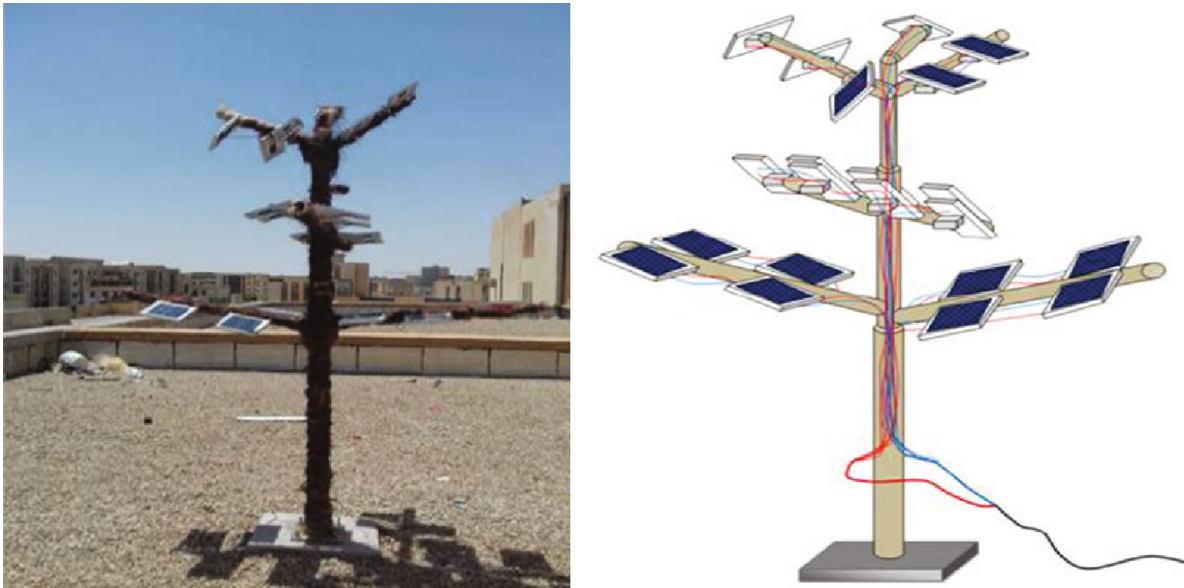

Figure 6: Solar tree.

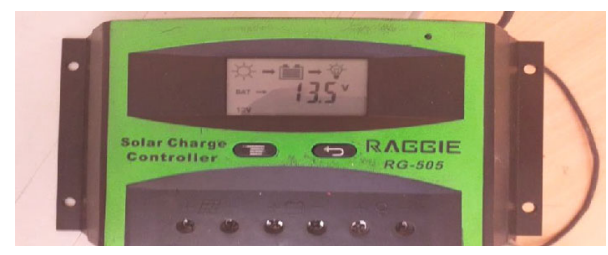

FIgURE 7: Used regulator.

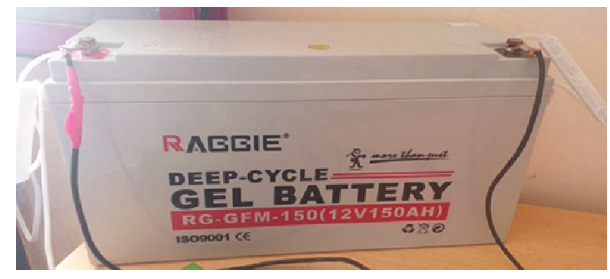

Figure 8: Adapted battery.

TABLE 2: The intensity according to the inclination.

\begin{tabular}{lc}
\hline Inclination with respect to the horizontal (deg.) & Intensity $(\mathrm{V})$ \\
\hline $0^{\circ}$ & 1.64 \\
$5^{\circ}$ & 1.39 \\
$10^{\circ}$ & 2.24 \\
$15^{\circ}$ & 2.89 \\
$20^{\circ}$ & 3.23 \\
$25^{\circ}$ & 3.26 \\
$30^{\circ}$ & 3.45 \\
$35^{\circ}$ & 3.78 \\
$40^{\circ}$ & 2.84 \\
\hline
\end{tabular}

TABLE 3: Results of the current and voltage.

\begin{tabular}{lcc}
\hline & Potential $U(\mathrm{~V})$ & Current $I(\mathrm{~mA})$ \\
\hline All cells are illuminated & 20.1 & 3.5 \\
1 cell is in the shade & 20.1 & 2.9 \\
\hline
\end{tabular}

when the $V$ value is above 20.5 volts; the solar tree model produces the largest value of current.

In Figure 11, the electric power supplied by the fixed panels and the solar tree as a function of time is illustrated, where the maximum of the measurement error is about $3.75 \%$. The specified time range, from 11 am to $1 \mathrm{pm}$, gives the best conditions for a high performance for the first system, i.e., solar tree, as its power reached about 75 watts at midday, while the power is about 58 watts for the case of using the second model at $2 \mathrm{pm}$. The figure also highlights a power improvement in the case of the proposed new model (solar tree) compared to the traditional one provided (solar panel), for the specified time range between 8 am and 2:30 $\mathrm{pm}$. On the other hand, the traditional model values improve if the time dimension is extended from $2: 30 \mathrm{pm}$ to $6: 00 \mathrm{pm}$.

This is due to the effect of the negative temperature, where the efficiency of the solar tree is better than that of the installed solar panel in the morning, while in the evening, the efficiency of the solar panel was better than that of the solar tree. This is due to the temperature of the region and the presence of interstellar spaces between the cells of the solar tree $[53,54]$.

5.4. Parameters Affecting Tree Performance. To optimize the efficiency of the cells of the tree, the overall energy of the luminous flux, i.e., the diffuse energy and the direct energy, was taken into account. The cells heat up too much they produce less energy. To improve their yields, favorable conditions that will allow the proper functioning of the PV system must be proposed and be designed $[55,56]$.

\section{Conclusion}

In this experimental study, a prototype of an artificial solar tree is addressed by using materials available in the local market: solar cells, metal support, electrical cables, regulator, and battery. This model is used to replace the leaves of the tree by 25 solar cells, which imitate the appearance of a tree whose leaves are replaced by photovoltaic cells. 


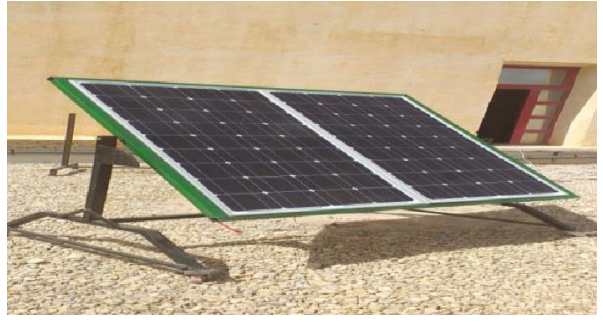

Figure 9: Electrical measurement of the tree and fixed panels.

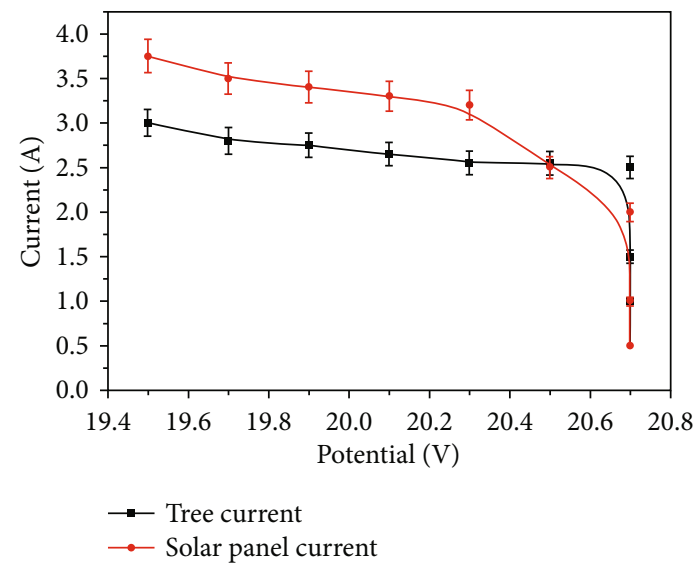

FIgURE 10: Current according to the voltage.

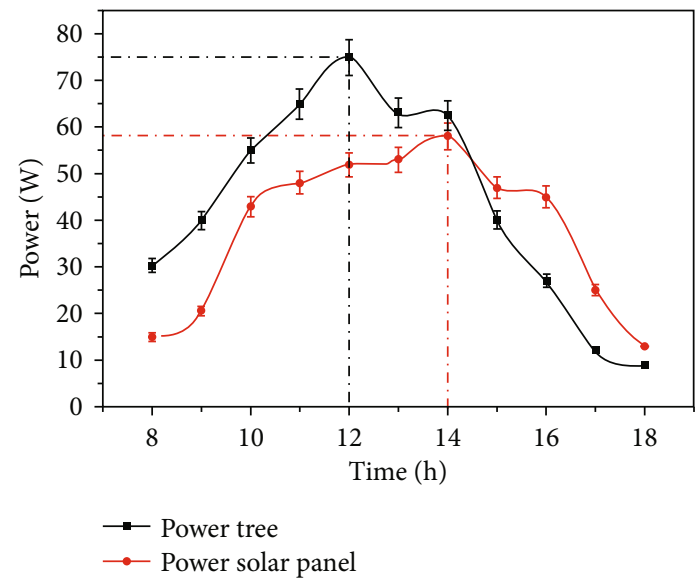

FIGURE 11: Variation in production power over time.

The predicted results in terms of the $I-V$ characteristic are approximately similar to the theoretical results, where the measurement error maximum is about $0.18 \%$.

The $I-V$ characteristic comparison proves that in the case of using the solar panel, it gave high $I$ values at $V<20.5$ volts; 3.00 A was reported in the case of the PV first model, i.e. solar panel, at the minimum tension value $(19.5 \mathrm{~V})$, while $3.75 \mathrm{~A}$ was highlighted in the case of the PV second model, i.e. solar tree, at the same $I$ minimum, while there is a difference when the $V$ value is above 20.5 volts; the solar tree model produced the largest value of current.

The specified time range, from $11 \mathrm{am}$ to $1 \mathrm{pm}$, gave the best conditions for a high performance for the first system, i.e., solar tree, as its power reached about 75 watts at midday, while the power was about 58 watts for the case of using the second model at $2 \mathrm{pm}$.

The result analysis also highlighted an electric power improvement in the case of the proposed new model, i.e., solar tree, compared to the traditional one provided, i.e., solar panel, for the specified time range between 8 am and 2:30 pm. On the other hand, the traditional model values improved if the time dimension is extended from 2:30 pm to 6:00 pm.

In general, the efficiency of the solar tree was better than that of the installed solar panel in the morning, while in the evening, the efficiency of the solar panel was better than that of the solar tree and this is due to the temperature of the region and the presence of interstellar spaces between the cells of the solar tree.

The advantage of the realization of the solar tree is to limit the maximum surface of the design. The performance of photovoltaic systems is strongly affected by climatological parameters (solar radiation and temperature) and by the type of solar cell.

Then, the results found are encouraged by proposing to do in the future a study of large solar tree installed within the university pole of M'sila.

\section{Data Availability}

The data used to support the findings of this study are included within the article.

\section{Conflicts of Interest}

The authors declare that they have no conflicts of interest.

\section{Acknowledgments}

The authors would like to thank the Direction Générale de la Recherche Scientifique et du Développement Technologique (DGRSDT) of the Ministry of Higher Education and Scientific Research in Algeria, which sponsored this work.

\section{References}

[1] A. Naveen Chakkaravarthy, M. Subathra, P. Jerin Pradeep, and N. Manoj Kumar, "Solar irradiance forecasting and energy optimization for achieving nearly net zero energy building," Journal of Renewable and Sustainable Energy, vol. 10, no. 3, article 035103, 2018.

[2] N. Kannan and D. Vakeesan, "Solar energy for future world: -a review," Renewable and Sustainable Energy Reviews, vol. 62, pp. 1092-1105, 2016.

[3] E. A. Lawin, S. D. Bazyomo, and A. Ouedraogo, "Solar photovoltaic energy and electricity security on ECOWAS countries," Journal of Renewable Energy, vol. 2017, Article ID 7142350, 9 pages, 2017.

[4] A. Shukla, K. Sudhakar, and P. Baredar, "Renewable energy resources in South Asian countries: Challenges, policy and recommendations," Resource-Efficient Technologies, vol. 3, no. 3, pp. 342-346, 2017. 
[5] M. H. Ahmadi, M. Ghazvini, M. Sadeghzadeh et al., "Solar power technology for electricity generation: a critical review," Energy Science \& Engineering, vol. 6, no. 5, pp. 340-361, 2018.

[6] S. Yadav and K. Sudhakar, "Different domestic designs of solar stills: a review," Renewable and Sustainable Energy Reviews, vol. 47, pp. 718-731, 2015.

[7] C. S. Jwo, S. L. Chen, H. Chang, Y.-S. Su, and J.-S. Chen, "Solar energy and clean energy: trends and developments," International Journal of Photoenergy, vol. 2013, Article ID 749167, 2 pages, 2013.

[8] M. Sadeghzadeh, M. H. Ahmadi, M. Kahani, H. Sakhaeinia, H. Chaji, and L. Chen, "Smart modeling by using artificial intelligent techniques on thermal performance of flat-plate solar collector using nanofluid," Energy Science \& Engineering, vol. 7, no. 5, pp. 1649-1658, 2019.

[9] J. Aggarwal and M. L. Aggarwal, "Harnessing Solar Energy for Every Home: Energy Saving Applications," Conference Papers in Science, vol. 2014, Article ID 628294, 3 pages, 2014.

[10] M. Chelbi, Y. Gagnon, and J. Waewsak, "Solar radiation mapping using sunshine duration-based models and interpolation techniques: application to Tunisia," Energy Conversion and Management, vol. 101, pp. 203-215, 2015.

[11] M. H. Ahmadi, M. Alhuyi Nazari, R. Ghasempour, F. Pourfayaz, M. Rahimzadeh, and T. Ming, "A review on solar-assisted gas turbines," Energy Science \& Engineering, vol. 6, no. 6, pp. 658-674, 2018.

[12] I. E. Ghoujdi, H. Hadiannasab, M. Bidi et al., "Multiobjective optimization design of the solar field and reverse osmosis system with preheating feed water using genetic algorithm," Energy Science \& Engineering, vol. 6, no. 6, pp. 624-642, 2018.

[13] M. A. Vakilabadi, M. Bidi, A. F. Najafi, and M. H. Ahmadi, "Exergy analysis of a hybrid solar-fossil fuel power plant," Energy Science \& Engineering, vol. 7, no. 1, pp. 146-161, 2019.

[14] A. M. Pringle, R. M. Handler, and J. M. Pearce, "Aquavoltaics: synergies for dual use of water area for solar photovoltaic electricity generation and aquaculture," Renewable and Sustainable Energy Reviews, vol. 80, pp. 572-584, 2017.

[15] M. Ghodbane and B. Boumeddane, "Estimating solar radiation according to semi empirical approach of Perrin de Brichambaut: application on several areas with different climate in Algeria," International Journal of Energetica, vol. 1, no. 1, p. 20, 2016.

[16] M. H. Ahmadi, A. Baghban, M. Sadeghzadeh et al., "Evaluation of electrical efficiency of photovoltaic thermal solar collector," Engineering Applications of Computational Fluid Mechanics, vol. 14, no. 1, pp. 545-565, 2020.

[17] I. H. Altas and A. M. Sharaf, "Solar energy and PV systems," International Journal of Photoenergy, vol. 2014, Article ID 408285, 2 pages, 2014.

[18] N. Katayama, S. Osawa, S. Matsumoto, T. Nakano, and M. Sugiyama, "Degradation and fault diagnosis of photovoltaic cells using impedance spectroscopy," Solar Energy Materials and Solar Cells, vol. 194, pp. 130-136, 2019.

[19] L. Hernández-Callejo, S. Gallardo-Saavedra, and V. AlonsoGómez, "A review of photovoltaic systems: Design, operation and maintenance," Solar Energy, vol. 188, pp. 426-440, 2019.

[20] M. Gruber, V. Jovanov, and V. Wagner, "Modeling of photoactive area spreading in unstructured photovoltaic cells," Solar Energy Materials and Solar Cells, vol. 200, article 110011, 2019.

[21] A. Antonacci and V. Scognamiglio, "Photosynthesis-based hybrid nanostructures: electrochemical sensors and photovol- taic cells as case studies," TrAC Trends in Analytical Chemistry, vol. 115, pp. 100-109, 2019.

[22] Y. Jeong, D. Shin, J. H. Park, J. Park, Y. Yi, and S. Im, "Integrated advantages from perovskite photovoltaic cell and $2 \mathrm{D}$ $\mathrm{MoTe}_{2}$ transistor towards self-power energy harvesting and photosensing," Nano Energy, vol. 63, article 103833, 2019.

[23] H. Karami Lakeh, H. Kaatuzian, and R. Hosseini, “A parametrical study on photo-electro-thermal performance of an integrated thermoelectric-photovoltaic cell," Renewable Energy, vol. 138, pp. 542-550, 2019.

[24] M. Shaygan, M. A. Ehyaei, A. Ahmadi, M. E. H. Assad, and J. L. Silveira, "Energy, exergy, advanced exergy and economic analyses of hybrid polymer electrolyte membrane (PEM) fuel cell and photovoltaic cells to produce hydrogen and electricity," Journal of Cleaner Production, vol. 234, pp. 1082-1093, 2019.

[25] S. Malathy and R. Ramaprabha, "A two-stage tracking algorithm for PV systems subjected to partial shading conditions," International Journal of Renewable Energy Research, vol. 8, no. 4, pp. 2249-2256, 2018.

[26] Y. K. Wu, C. R. Chen, and H. Abdul Rahman, "A novel hybrid model for short-term forecasting in PV power generation," International Journal of Photoenergy, vol. 2014, Article ID 569249, 9 pages, 2014.

[27] K. Araki and M. Yamaguchi, "Novel equivalent circuit model and statistical analysis in parameters identification," Solar Energy Materials and Solar Cells, vol. 75, no. 3-4, pp. 457466, 2003

[28] Q. Wang, S. Ji, M. Hu, W. Li, F. Liu, and L. Zhu, "Short-term photovoltaic power generation combination forecasting method based on similar day and cross entropy theory," International Journal of Photoenergy, vol. 2018, Article ID 6973297, 10 pages, 2018.

[29] J. Merten, J. M. Asensi, C. Voz, A. V. Shah, R. Platz, and J. Andreu, "Improved equivalent circuit and analytical model for amorphous silicon solar cells and modules," IEEE Transactions on Electron Devices, vol. 45, no. 2, pp. 423-429, 1998.

[30] H. A. Kazem and T. Khatib, "A novel numerical algorithm for optimal sizing of a photovoltaic/wind/diesel generator/battery microgrid using loss of load probability Index," International Journal of Photoenergy, vol. 2013, Article ID 718596, 8 pages, 2013.

[31] T. Ikegami, T. Maezono, F. Nakanishi, Y. Yamagata, and K. Ebihara, "Estimation of equivalent circuit parameters of PV module and its application to optimal operation of PV system," Solar Energy Materials and Solar Cells, vol. 67, no. 1-4, pp. 389-395, 2001.

[32] V. Jha and U. S. Triar, "An improved generalized method for evaluation of parameters, modeling, and simulation of photovoltaic modules," International Journal of Photoenergy, vol. 2017, Article ID 2532109, 19 pages, 2017.

[33] V. Quaschning and R. Hanitsch, "Numerical simulation of current-voltage characteristics of photovoltaic systems with shaded solar cells," Solar Energy, vol. 56, no. 6, pp. 513-520, 1996.

[34] R. Xie, J. Su, M. Li, and L. Guo, "Structural and Photoelectrochemical properties of $\mathrm{Cu}$-doped CdS thin films prepared by ultrasonic spray pyrolysis," International Journal of Photoenergy, vol. 2013, Article ID 620134, 7 pages, 2013.

[35] L. El Iysaouy, L. Mhammed, and O. Abdelmajid, "Enhancing the performances of PV Array configurations under partially shaded conditions: a comparative study," International 
Journal of Renewable Energy Research, vol. 8, no. 3, pp. 17791790, 2018.

[36] O. K. Echendu, F. B. Dejene, I. M. Dharmadasa, and F. C. Eze, "Characteristics of nanocrystallite-CdS Produced by low-cost electrochemical technique for thin film photovoltaic application: the influence of deposition voltage," International Journal of Photoenergy, vol. 2017, Article ID 3989432, 13 pages, 2017.

[37] A. Bouraiou, M. Hamouda, A. Chaker, M. Sadok, M. Mostefaoui, and S. Lachtar, "Modeling and simulation of photovoltaic module and array based on one and two diode model using Matlab/Simulink," Energy Procedia, vol. 74, pp. 864-877, 2015.

[38] G. Ciulla, V. Lo Brano, and E. Moreci, "Forecasting the cell temperature of PV modules with an adaptive system," International Journal of Photoenergy, vol. 2013, Article ID 192854, 10 pages, 2013.

[39] Y. Huang, C. Chan, S. Kuan, S. Wang, and S. Lee, "Analysis and monitoring results of a building integrated photovoltaic façade using PV ceramic tiles in Taiwan," International Journal of Photoenergy, vol. 2014, Article ID 615860, 12 pages, 2014.

[40] A. F. Abdul Kadir, T. Khatib, and W. Elmenreich, "Integrating photovoltaic systems in power system: power quality impacts and optimal planning challenges," International Journal of Photoenergy, vol. 2014, Article ID 321826, 7 pages, 2014.

[41] M. A. Chaaban, L. El Chaar, and M. Alahmad, "An adaptive photovoltaic topology to overcome shading effect in PV systems," International Journal of Photoenergy, vol. 2015, Article ID 294872, 9 pages, 2015.

[42] M. Ali, M. H. Iqbal, N. A. Sheikh et al., "Performance investigation of air velocity effects on PV modules under controlled conditions," International Journal of Photoenergy, vol. 2017, Article ID 3829671, 10 pages, 2017.

[43] M. R. Yaiche, A. Bouhanik, S. M. E. A. Bekkouche, and T. Benouaz, "A new modelling approach intended to develop maps of annual solar irradiation and comparative study using satellite data of Algeria," Journal of Renewable and Sustainable Energy, vol. 8, no. 4, article 43702, 2016.

[44] M. A. M. Ramli, S. Twaha, and Y. A. Al-Turki, "Investigating the performance of support vector machine and artificial neural networks in predicting solar radiation on a tilted surface: Saudi Arabia case study," Energy Conversion and Management, vol. 105, pp. 442-452, 2015.

[45] A. Ben Othman, K. Belkilani, and M. Besbes, "Global solar radiation on tilted surfaces in Tunisia: measurement, estimation and gained energy assessments," Energy Reports, vol. 4, pp. 101-109, 2018.

[46] D. Yang, "Solar radiation on inclined surfaces: corrections and benchmarks," Solar Energy, vol. 136, pp. 288-302, 2016.

[47] "Photovoltaic Geographical Information System (PVGIS), EU Science Hub," March, 2020 https://ec.europa.eu/jrc/en/pvgis.

[48] P. Gangwar, R. Singh, R. P. Tripathi, and A. K. Singh, "Effective solar power harnessing using a few novel solar tree designs and their performance assessment," Energy Sources, Part A: Recovery, Utilization, and Environmental Effects, vol. 41, no. 15, pp. 1828-1837, 2019.

[49] F. Hyder, K. Sudhakar, and R. Mamat, "Solar PV tree design: a review," Renewable and Sustainable Energy Reviews, vol. 82, pp. 1079-1096, 2018.

[50] W. Cao, Z. Li, Y. Yang et al., "Solar tree: exploring new form factors of organic solar cells," Renewable Energy, vol. 72, pp. 134-139, 2014.
[51] S. MadhuPriya and K. Divya, "Solar tree - an artistic design to arrange solar panels," International Journal \& Magazine of Engineering, Technology, Management and Research, 2014.

[52] "Ross Lovegrove's solar tree," http://www.yuvaengineers.com/ wpcontent/uploads/2014/01/solar-3and4.png.

[53] S. Dey, M. K. Lakshmanan, and B. Pesala, "Optimal solar tree design for increased flexibility in seasonal energy extraction," Renewable Energy, vol. 125, pp. 1038-1048, 2018.

[54] C. Berthod, R. Strandberg, G. H. Yordanov, H. G. Beyer, and J. O. Odden, "On the variability of the temperature coefficients of mc-Si solar cells with irradiance," Energy Procedia, vol. 92, pp. 2-9, 2016.

[55] M. Zamen, A. Baghban, S. M. Pourkiaei, and M. H. Ahmadi, "Optimization methods using artificial intelligence algorithms to estimate thermal efficiency ofPV/T system," Energy Science \& Engineering, vol. 7, no. 3, pp. 821-834, 2019.

[56] R. A. Ferdaus, M. A. Mohammed, S. Rahman, S. Salehin, and M. A. Mannan, "Energy Efficient Hybrid Dual Axis Solar Tracking System," Journal of Renewable Energy, vol. 2014, Article ID 629717, 12 pages, 2014. 